Vol. 9 (2000): 279-289.

\title{
Assessment of genetic diversity using RAPD analysis in a germplasm collection of sea buckthorn
}

\author{
Galyna I. Bartish \\ Balsgård - Department of Horticultural Plant Breeding, Swedish University of Agricultural Sciences, \\ Fjälkestadsvägen 123-1, S-29194 Kristianstad, Sweden. Current address: Natural Science Section, \\ Södertörn University College, PO Box 4101, S-14104 Huddinge, Sweden \\ Niklas Jeppsson \\ Balsgård - Department of Horticultural Plant Breeding, Swedish University of Agricultural Sciences, \\ Fjälkestadsvägen 123-1, S-29194 Kristianstad, Sweden \\ Igor V. Bartish \\ Balsgård - Department of Horticultural Plant Breeding, Swedish University of Agricultural Sciences, \\ Fjälkestadsvägen 123-1, S-29194 Kristianstad, Sweden. Current address: Institute of Botany, Academy of \\ Sciences, CZ-25243 Pruhonice 1, Czech Republic \\ Hilde Nybom \\ Balsgård - Department of Horticultural Plant Breeding, Swedish University of Agricultural Sciences, \\ Fjälkestadsvägen 123-1, S-29194 Kristianstad, Sweden,e-mail: Hilde.Nybom@hvf.slu.se
}

Random amplified polymorphic DNA (RAPD) markers were used to characterize a part of a sea buckthorn gene bank collected for plant breeding purposes. Molecular markers were generated in 55 cultivars and accessions, representing five subspecies of Hippophae rhamnoides $\mathrm{L}$. and intraspecific hybrids between different subspecies. Sixty-three markers were used to generate a Dice's similarity coefficient matrix of pairwise comparisons between individual RAPD profiles. Cluster (UPGMA) and principal co-ordinate analyses, based on this matrix, revealed clustering of plants into groups which generally correspond to their taxonomic classification or geographic origin. The analysis of molecular variance (AMOVA) was found useful for estimating components of genetic variation between and within taxonomic and geographic groups of accessions and cultivars. Whereas both alternatives for grouping the material (taxonomic or geographic origin) resulted in significant betweengroup variation, the major part of molecular variance (approximately 75\%) was still attributed to variation within groups. We conclude that the RAPD analysis is useful for clarification of taxonomic and geographic origin of accessions and cultivars of sea buckthorn.

Key words: sea buckthorn, Hippophae rhamnoides, genetic diversity, RAPD, core collection, hybridization 


\section{AGRICULTURAL AND FOOD SCIENCE IN FINLAND}

Bartish, G.I. et al. RAPD diversity in sea buckthorn

\section{Introduction}

A number of plant species, that have only rarely been cultivated in the past, are now being investigated for possible domestication with the goal to diversify farming and to introduce crops that are amenable to organic production methods. One such crop, that has recently received increased attention, is the sea buckthorn, Hippophae rhamnoides $\mathrm{L}$. This is an outcrossing dioecious pioneer plant, that occurs mainly along rivers in mountainous regions but also on sea shores. It has a wide but discontinuous distribution throughout Europe and Asia, from the north of Europe to central China. The species is further divided into nine subspecies (Rousi 1971). Its berries can be used for juice and jam production. However, these berries also contain aromatic and medicinal compounds that can be extracted and used e.g. in functional food products, in medicine and in cosmetics. The plant itself is widely used for its ornamental value and for the prevention of soil erosion (Trajkovski and Jeppsson 1999).

Domestication of sea buckthorn started in Siberia in the 1930s (Kalinina and Panteleyeva 1987) with local germplasm (ssp. mongolica). The interest increased and it was soon introduced to other regions of Russia and to neighbouring countries (Trajkovski and Jeppsson 1999). The need for plant material, that was adapted to the local climate, prompted the onset of breeding programmes, which have generated numerous cultivars. At present, more than 60 cultivars have been described (Trajkovski and Jeppsson 1999). In addition to ssp. mongolica and ssp. turkestanica of central Asian origin, the European subspecies rhamnoides and carpatica and ssp. caucasica from Minor Asia have also been utilized for breeding purposes. Hybridization between these different subspecies has been used extensively in efforts to combine traits from superior genotypes.

Possibly one of the world's most diverse Hippophae gene banks is now available at Balsgård - Department of Horticultural Plant Breeding,
S. Sweden. This gene bank is composed of all the wild taxa in the genus from different parts of the world, as well as cultivars and selections from different breeding programmes. Knowledge of genetic relatedness among accessions of a germplasm collection is necessary for development of conservation strategies, since the aim is to preserve as much variability as possible with a minimum repetitiveness. Most crop germplasm collections contain a considerable percentage of misclassified accessions, which may seriously affect the use of germplasm for horticultural improvement. The efficient organization of gene bank resources is therefore an important task, and a core collection should be developed (Hokanson et al. 1998). Such a subset of the entire germplasm collection should, ideally, represent the genetic diversity found within the whole collection. In addition, information about levels of relatedness can, for example, enable the breeder to take advantage of the heterosis effect produced by hybridization between genetically distant genotypes. Unfortunately, information about taxonomic and geographic origin is not always available for gene bank accessions, not even when these consist of recently marketed cultivars.

The present study was performed to study genetic relatedness and diversity in a small subset of the Hippophae gene bank at Balsgård. This subset was composed of accessions from native $H$. rhamnoides populations, cultivars and selections from different breeding programmes. We used random amplified polymorphic DNA (RAPD), which has been shown to be one of the most cost-effective methods for obtaining polymorphic markers in many plant genera (Tivang et al. 1996, Bartish et al. 1999b, Virk et al. 2000). In sea buckthorn, RAPD analysis has recently been applied to studying the partitioning of genetic variation in plants from native stands (Bartish et al. 1999a) and to develop a marker for sex determination (Persson and Nybom 1999). In addition, a representative sample of all presently recognized taxa in the genus Hippophae has been subjected to a phenetic analysis using RAPD markers (Bartish et al. 2000). This infor- 
Vol. 9 (2000): 279-289.

mation will be used in the process of developing a core collection of sea buckthorn.

\section{Material and methods}

\section{Plant material and DNA extraction}

We selected 55 plants of Hippophae rhamnoides L. including subspecies carpatica, caucasica, fluviatilis, mongolica, and rhamnoides. Information about geographic origin of these accessions was available in most cases (Table 1) and was used to divide the collection into groups. Two approaches for this division were applied: geographic origin (10 groups) and classification (6 groups; i.e. 5 subspecies and the inter-subspecific hybrids). Dormant shoots were collected in January and forced, in a greenhouse, to produce fresh leaves. DNA extraction from leaf tissue and generation of RAPD markers was performed according to Bartish et al. (2000).

\section{RAPD analysis}

Initial screening of decamer primers has been performed previously on Hippophae sp. material (Persson and Nybom 1999, Bartish et al. 1999a). We selected eight primers from Operon Technologies, Inc., based on the presence of polymorphism, the ability to discriminate between populations, and the reproducibility of amplifications (Table 2). PCR amplifications were performed according to Bartish et al. (2000). Amplification products were separated by electrophoresis in $1.8 \%$ agarose gels in $1 \mathrm{x}$ TPE buffer (Weising et al. 1994), stained with ethidium bromide, and documented under UV light with polaroid photography.

\section{Data analysis}

Each polymorphic band in the RAPD profile was treated as an independent locus with two alleles, based on the presence or absence of the band. Amplification products were scored manually, 1 for presence and 0 for absence. A binary matrix was generated based on 63 polymorphic RAPD bands. Only reliably scored bands with a size of 200-1600 bp were included in the analysis.

Dice's coefficient of similarity was calculated for all pairwise comparisons between individual samples from the binary RAPD data matrix according to the formula

$\% \mathrm{~S}_{\mathrm{AB}}=\left[2 \mathrm{~N}_{\mathrm{AB}} /\left(\mathrm{N}_{\mathrm{A}}+\mathrm{N}_{\mathrm{B}}\right)\right] 100$,

where $\% \mathrm{~S}_{\mathrm{AB}}$ is the coefficient of similarity between individuals $\mathrm{A}$ and $\mathrm{B}, \mathrm{N}_{\mathrm{A}}$ and $\mathrm{N}_{\mathrm{B}}$ is the number of bands for sample $A$ and $B$ respectively, and $\mathrm{N}_{\mathrm{AB}}$ is the number of shared bands for $\mathrm{A}$ and $\mathrm{B}$. This matrix was analysed by cluster analysis (UPGMA method, SAHN program, NTSYSpc, Rohlf 1997). Additional information about genetic relationships between individual plants was derived by principal co-ordinate analysis (PCO, DECENTER and EIGENVECTOR programs, NTSYS-pc) by which a two-dimensional plot was obtained.

A second matrix, this time using Euclidean distances among all individual plants, was computed from the binary RAPD data matrix. We used this new matrix as an input distance matrix for an Analysis of Molecular Variance (AMOVA), as in Excoffier et al. (1992) and Huff et al. (1993), for partitioning the genetic variance into components within and among plant groups and for testing the significance of the estimates obtained.

\section{Results and discussion}

RAPD analysis of 8 decamer primers revealed 63 polymorphic $(86.3 \%)$ and 10 monomorphic markers (Table 2), indicating a relatively high diversity in our plant sample, which thus provides a promising foundation for further breed- 
Bartish, G.I. et al. RAPD diversity in sea buckthorn

Table 1. Geographical origin and taxonomic classification of the plant material. ? somewhat uncertain origin, ?? very uncertain origin.

\begin{tabular}{|c|c|c|c|}
\hline Clone & Type & Origin & Subspecies \\
\hline $\begin{array}{l}\text { 'Askola' } \\
\text { 'Friesdorfer Orange' } \\
\text { 'Hergo' } \\
\text { 'Leikora' } \\
\text { 'Pollmix' }\end{array}$ & $\begin{array}{l}\text { Cultivar } \\
\text { Cultivar } \\
\text { Cultivar } \\
\text { Cultivar } \\
\text { Cultivar }\end{array}$ & $\begin{array}{l}\text { Germany } \\
\text { Germany } \\
\text { Germany } \\
\text { Germany } \\
\text { Germany }\end{array}$ & $\begin{array}{l}\text { rhamnoides } \\
\text { rhamnoides?? } \\
\text { rhamnoides } \\
\text { rhamnoides } \\
\text { rhamnoides }\end{array}$ \\
\hline $\begin{array}{l}\text { 'Botanicheskaya' } \\
\text { 'Finskaya' } \\
\text { 'Gibrid Persika' } \\
\text { 'Lubitelskaya' } \\
\text { 'Otradnaya' } \\
\text { 'Persik' } \\
\text { 'Prozrachnaya' } \\
\text { 'Tolme' } \\
\text { 'Trofimovskaya' }\end{array}$ & $\begin{array}{l}\text { Cultivar } \\
\text { Cultivar } \\
\text { Cultivar } \\
\text { Cultivar } \\
\text { Cultivar } \\
\text { Cultivar } \\
\text { Cultivar } \\
\text { Cultivar } \\
\text { Cultivar }\end{array}$ & $\begin{array}{l}\text { Moscow (Russia) } \\
\text { Moscow (Russia) } \\
\text { Moscow (Russia) } \\
\text { Moscow (Russia) } \\
\text { Moscow (Russia) } \\
\text { Moscow (Russia) } \\
\text { Moscow (Russia) } \\
\text { Moscow (Russia) } \\
\text { Moscow (Russia) }\end{array}$ & $\begin{array}{l}\text { mongolica X rhamnoides } \\
\text { mongolica X rhamnoides } \\
\text { mongolica X rhamnoides } \\
\text { mongolica X rhamnoides } \\
\text { mongolica X rhamnoides } \\
\text { mongolica X rhamnoides } \\
\text { mongolica X rhamnoides } \\
\text { mongolica X rhamnoides?? } \\
\text { mongolica X rhamnoides }\end{array}$ \\
\hline $\begin{array}{l}\text { 'Henry' } \\
\text { 'Oranzhevaya' } \\
10221 \\
10726 \\
10740 \\
10747 \\
10933 \\
10941 \\
72656 \\
72668 \\
1302136 \\
1302142 \\
72870 \\
72880 \\
130323\end{array}$ & $\begin{array}{l}\text { Cultivar } \\
\text { Cultivar } \\
\text { Selection } \\
\text { Selection } \\
\text { Selection } \\
\text { Selection } \\
\text { Selection } \\
\text { Selection } \\
\text { Selection } \\
\text { Selection } \\
\text { Selection } \\
\text { Selection } \\
\text { Wild } \\
\text { Wild } \\
\text { Wild }\end{array}$ & $\begin{array}{l}\text { Siberia?(Russia) } \\
\text { Siberia (Russia) } \\
\text { Siberia (Russia) } \\
\text { Siberia (Russia) } \\
\text { Siberia (Russia) } \\
\text { Siberia (Russia) } \\
\text { Siberia (Russia) } \\
\text { Siberia (Russia) } \\
\text { Siberia (Russia) } \\
\text { Siberia (Russia) } \\
\text { Siberia (Russia) } \\
\text { Siberia (Russia) } \\
\text { Siberia (Russia) } \\
\text { Siberia (Russia) } \\
\text { Siberia (Russia) }\end{array}$ & $\begin{array}{l}\text { mongolica?? } \\
\text { mongolica } \\
\text { mongolica? } \\
\text { mongolica? } \\
\text { mongolica? } \\
\text { mongolica? } \\
\text { mongolica? } \\
\text { mongolica? } \\
\text { mongolica? } \\
\text { mongolica? } \\
\text { mongolica? } \\
\text { mongolica? } \\
\text { mongolica } \\
\text { mongolica } \\
\text { mongolica }\end{array}$ \\
\hline $\begin{array}{l}\text { 'Julia' } \\
\text { 'Romeo' } \\
31617 \\
31806 \\
72503 \\
72504 \\
72505 \\
72588 \\
72591 \\
725132 \\
727102\end{array}$ & $\begin{array}{l}\text { Cultivar } \\
\text { Cultivar } \\
\text { Selection } \\
\text { Selection } \\
\text { Selection } \\
\text { Selection } \\
\text { Selection } \\
\text { Selection } \\
\text { Selection } \\
\text { Selection } \\
\text { Selection }\end{array}$ & $\begin{array}{l}\text { Balsgård (Sweden) } \\
\text { Balsgård (Sweden) } \\
\text { Balsgård (Sweden) } \\
\text { Balsgård (Sweden) } \\
\text { Balsgård (Sweden) } \\
\text { Balsgård (Sweden) } \\
\text { Balsgård (Sweden) } \\
\text { Balsgård (Sweden) } \\
\text { Balsgård (Sweden) } \\
\text { Balsgård (Sweden) } \\
\text { Balsgård (Sweden) }\end{array}$ & $\begin{array}{l}\text { mongolica X rhamnoides } \\
\text { mongolica X rhamnoides } \\
\text { mongolica X rhamnoides } \\
\text { mongolica X rhamnoides } \\
\text { mongolica X rhamnoides } \\
\text { mongolica X rhamnoides } \\
\text { mongolica X rhamnoides } \\
\text { mongolica X rhamnoides } \\
\text { mongolica X rhamnoides } \\
\text { mongolica X rhamnoides } \\
\text { mongolica X rhamnoides }\end{array}$ \\
\hline $\begin{array}{l}727156 \\
\text { 'Raisa' } \\
\text { 'Rudolf' }\end{array}$ & $\begin{array}{l}\text { Selection } \\
\text { Cultivar } \\
\text { Cultivar }\end{array}$ & $\begin{array}{l}\text { Rostov-on-Don (Russia) } \\
\text { Finland } \\
\text { Finland }\end{array}$ & $\begin{array}{l}\text { mongolica X rhamnoides } \\
\text { rhamnoides X caucasica } \\
\text { rhamnoides }\end{array}$ \\
\hline $\begin{array}{l}60865 \\
60866\end{array}$ & $\begin{array}{l}\text { Wild } \\
\text { Wild }\end{array}$ & $\begin{array}{l}\text { Switzerland } \\
\text { Switzerland }\end{array}$ & $\begin{array}{l}\text { fluviatilis } \\
\text { fluviatilis }\end{array}$ \\
\hline $\begin{array}{l}31910 \\
31917 \\
31928 \\
31929\end{array}$ & $\begin{array}{l}\text { Wild } \\
\text { Wild } \\
\text { Wild } \\
\text { Wild }\end{array}$ & $\begin{array}{l}\text { Uppland (Sweden) } \\
\text { Uppland (Sweden) } \\
\text { Uppland (Sweden) } \\
\text { Uppland (Sweden) }\end{array}$ & $\begin{array}{l}\text { rhamnoides } \\
\text { rhamnoides } \\
\text { rhamnoides } \\
\text { rhamnoides }\end{array}$ \\
\hline $\begin{array}{l}191034 \\
191229 \\
191230\end{array}$ & $\begin{array}{l}\text { Wild } \\
\text { Wild } \\
\text { Wild }\end{array}$ & $\begin{array}{l}\text { Dagestan (Russia) } \\
\text { Dagestan (Russia) } \\
\text { Dagestan (Russia) }\end{array}$ & $\begin{array}{l}\text { caucasica } \\
\text { caucasica } \\
\text { caucasica }\end{array}$ \\
\hline $\begin{array}{l}191378 \\
191379 \\
191383\end{array}$ & $\begin{array}{l}\text { Wild } \\
\text { Wild } \\
\text { Wild }\end{array}$ & $\begin{array}{l}\text { Transsylvania (Romania) } \\
\text { Transsylvania (Romania) } \\
\text { Transsylvania (Romania) }\end{array}$ & $\begin{array}{l}\text { carpatica } \\
\text { carpatica } \\
\text { carpatica }\end{array}$ \\
\hline
\end{tabular}


Vol. 9 (2000): 279-289.

Table 2. Primers used, number of polymorphic and monomorphic bands, and percentages of polymorphic bands.

\begin{tabular}{llccr}
\hline Primers & $\begin{array}{l}\text { Sequence } \\
\left(5^{\prime} \text { to 3') }\right.\end{array}$ & $\begin{array}{c}\text { Number of } \\
\text { polymorphic } \\
\text { bands }\end{array}$ & $\begin{array}{c}\text { Number of } \\
\text { monomorphic } \\
\text { bands }\end{array}$ & $\begin{array}{c}\text { Polymorphism } \\
\%\end{array}$ \\
\hline OPA-11 & CAATCGCCGT & 8 & 0 & 100 \\
OPA-15 & TTCCGAACCC & 6 & 2 & 75 \\
OPB-4 & GGACTGGAGT & 10 & 0 & 100 \\
OPB-18 & CCACAGCAGT & 7 & 3 & 70 \\
OPD-12 & CACCGTATCC & 8 & 2 & 80 \\
OPD-18 & GAGAGCCAAC & 9 & 1 & 90 \\
OPE-6 & AAGACCCCTC & 9 & 0 & 100 \\
\hline
\end{tabular}

ing activities. For comparison, the following levels of within-species RAPD polymorphism have been reported in other woody plant species: $58 \%$ in the endangered subtropical shrub Haloragodendron lucasii (Sydes and Peakall 1998), $61 \%$ in the tropical tree Gliricidia sepium (Chalmers et al. 1992), 80\% in the tropical tree Theobroma cacao (Russell et al. 1993), 92\% in the tropical tree Cedrela odorata (Gillies et al. 1997), 97\% in the endangered subtropical tree Caesalpinia echinata (Cardoso et al. 1998), and $98 \%$ in the endangered subtropical shrub Grevillea scapigera (Rossetto et al. 1995).

Partitioning molecular variation by AMOVA revealed that most variation resides within geographic or taxonomic groups $(75.3 \%$ and $76.0 \%$, respectively; $\mathrm{P}<0.001$; Table 3 ) in spite of the diverse geographic and taxonomic origins of the accessions studied. Similarly, within-subspecies variation was found to be considerably higher than between-subspecies variation in a previous RAPD study based on natural populations of several Hippophae species (Bartish et al. 2000).

The UPGMA dendrogram divides the studied individuals into three main groups and a few rather isolated single accessions. The first of these main groups consists mostly of cultivars, selections and wild accessions of ssp. mongolica from Siberia (Fig. 1). One noteworthy point is that within this group we find the Finnish cultivar 'Henry'. According to records at the nursery Jalaja Oy (Mr. Kettonen, personal communication), this clone was introduced from Nizh- ny Novgorod (Russia). Since breeding programmes on $H$. rhamnoides in Russia rely mostly on ssp. mongolica (Kalinina and Panteleyeva 1987), it is reasonable to believe that 'Henry' belongs to this subspecies. In somewhat peripheral positions in this group we find accession 31617 , which is a genotype selected from a hybrid progeny (mongolica x rhamnoides x caucasica) and accessions 1302136 and 1302142, which are claimed to have been raised from open pollination of 'Zyryanka', a cultivar reported to be a gamma-ray induced mutation of Baltic Sea origin (ssp. rhamnoides, Burmistrov 1995).

The second main group (Fig. 1) consists mostly of plants from different breeding programmes, and all of them, with only one excep-

Table 3. Partitioning of molecular variance into components by AMOVA at different hierarchical levels. Groups were defined according to Table 1 . All values are significant $(\mathrm{P}<0.001)$.

\begin{tabular}{lc}
\hline Hierarchial level of variance & Percentage of variation \\
\hline $\begin{array}{l}\text { Variation between taxonomic groups } \\
\text { Variation between geographic groups }\end{array}$ & 19.5 \\
$\quad$ within taxonomic groups & 7.0 \\
Variation within geographic groups & 73.5 \\
$\quad$ within taxonomic groups & 24.7 \\
Variation between geographic groups & 75.3 \\
Variation within geographic groups & 24.0 \\
Variation between taxonomic groups & 76.0 \\
\hline
\end{tabular}




\section{AGRICULTURAL AND FOOD SCIENCE IN FINLAND}

Bartish, G.I. et al. RAPD diversity in sea buckthorn

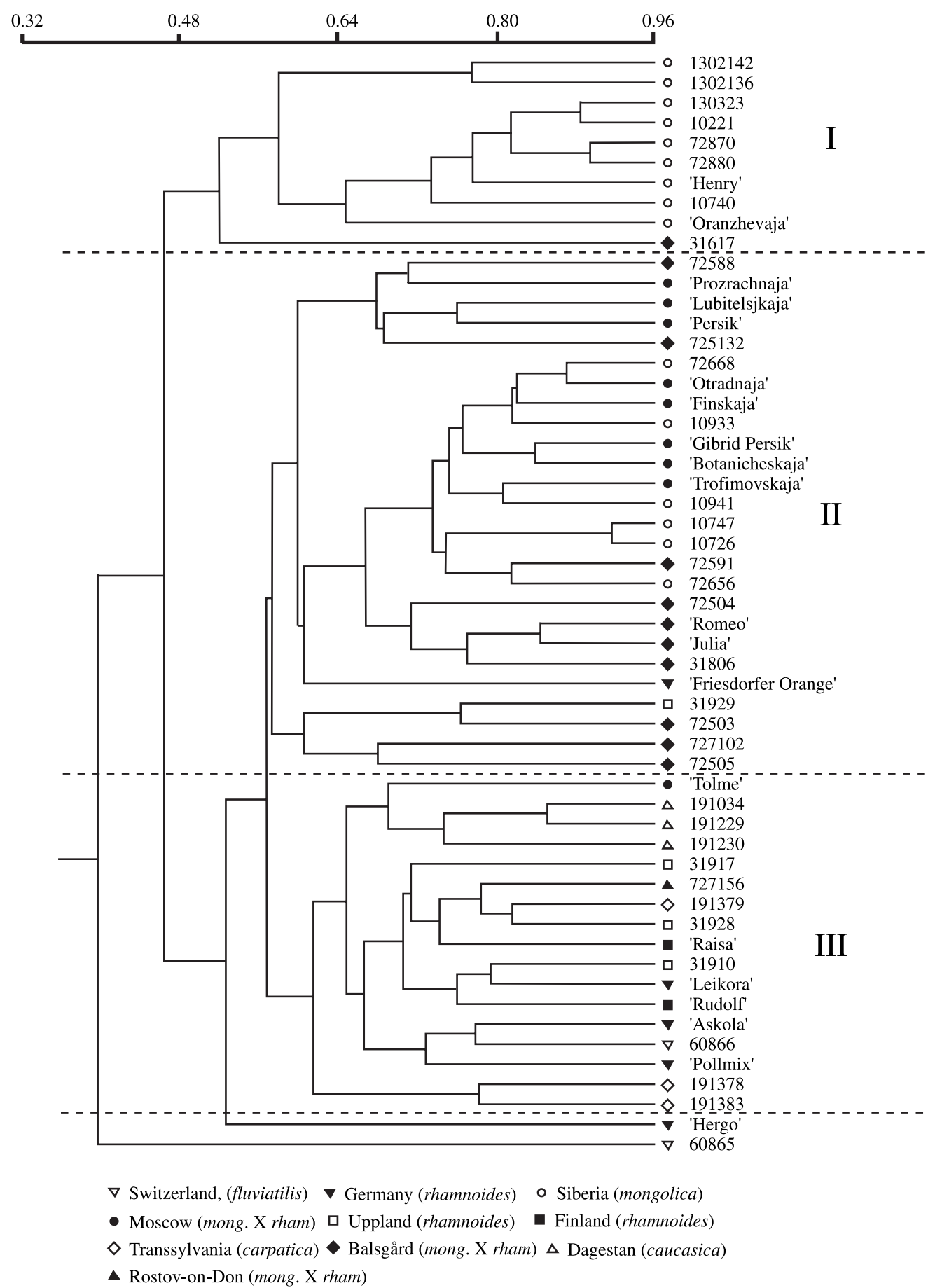

Fig. 1. UPGMA dendrogram based on RAPD data (Dice's pairwise coefficients of similarity) for 55 accessions of Hippophae rhamnoides. The symbols correspond to the division by geographic groups presented in Table 1. For labelling of symbols, see Fig. 2. 
Vol. 9 (2000): 279-289.

tion (accession 31929 from Uppland), belong to ssp. mongolica or are hybrids between ssp. mongolica and ssp. rhamnoides. 'Friesdorfer Orange', a German cultivar of unknown taxonomic origin, also clusters within this group.

The third main group (Fig. 1) consists of taxonomically diverse samples: wild accessions of subspecies carpatica, caucasica, fluviatilis and rhamnoides and cultivars obtained from Germany and Finland. All of the German cultivars in this cluster are derived from ssp. rhamnoides. By contrast, the Finnish cultivars represent a heterogeneous group: 'Tolme' was originally obtained from Moscow and its taxonomic origin is unknown, 'Raisa' is a hybrid between ssp. rhamnoides and ssp. caucasica, and 'Rudolf' is derived from ssp. rhamnoides (Dr. Saila Karhu, personal communication). The pronounced differentiation between ssp. mongolica on the one hand, and the other four subspecies on the other hand, is in good accordance with a previous RAPD-based study on natural populations (Bartish et al. 2000), which found ssp. mongolica to be rather well separated from the other four presently investigated subspecies, and instead very close to ssp. turkestanica.

In the present study, some sibling plants clustered closely as expected, e.g. the three halfsib pairs 1302142/1302136 (group I), 10933/10941 and 72656/72668 (group II). However, in other cases siblings were placed into different groups, e.g. the halfsib pair 10726 (group II) /10740 (group I). Another example is given by the halfsib pair 60865/60866 with 60866 grouped together with the other native European samples (group III), whereas 60865 has diverged strongly from all other accessions. Yet other sibling progenies show intermediate clustering; e.g. the halfsibs 'Romeo', 'Julia' and 31806 grouped closely (group II) whereas the fourth sibling, 31617 , was placed in group I. The fullsib group $72503 / 72504 / 72505$ was rather dispersed but still all were placed within group II.

Results of the principal component analysis (Fig. 2) were generally congruent with the UPGMA dendrogram and the same main groups could be distinguished. Two plants did not cluster with any of these main groups; one is a wild accession of ssp. fluviatilis (60865) and another (31617) is a hybrid, obtained at Balsgård from open pollination with participation of three subspecies (ssp. caucasica, ssp. mongolica and ssp. rhamnoides).

One of the main groups (ellipse A) includes only plants from ssp. mongolica and the second group (ellipse B) includes mainly hybrids between ssp. rhamnoides and ssp. mongolica. Several plants within this group were obtained from a Siberian breeding program (Lisavenko institute, Barnaul, Siberia). In addition to plants belonging to ssp. mongolica, this breeding programme used wild accessions of ssp. rhamnoides from Baltic populations as a source of additional genetic diversity (Kalinina and Panteleyeva 1987). A hybrid origin was actually verified for accessions 10933 and 10941 by the original letter that was included with the seed introduction. The cultivars 'Trofimovskaya' and 'Botanicheskaya' were obtained at the Botanical garden of Moscow University, by open pollination of plants from ssp. rhamnoides which grew together with plants from ssp. mongolica (Mikheyev and Demenko 1990). Accessions 10740 and 10747 are derived from the cultivar 'Zolotoy Pochatok', which was selected from wild populations of ssp. mongolica from Siberia (Kalinina and Panteleyeva 1987). Since accession 10747 was placed among hybrids of mongolica $\mathrm{x}$ rhamnoides (Fig. 2, ellipse B), we can hypothesise that this plant also contains genetic material from ssp. rhamnoides. The cultivars 'Persik' and 'Otradnaya' were developed at the Botanical Garden of Moscow University, by open pollination of wild populations from the Saint-Petersburg area (Mikheyev and Demenko 1990). Although they have a similar origin, the PCO plot reveals considerable differentiation between them and suggests that introgression from ssp. mongolica was more pronounced in the cultivar 'Otradnaya'.

Ellipse C on the PCO plot contains representatives of all subspecies, apart from ssp. mongolica. The cultivars from Germany and Finland are more heterogeneous genetically than the wild 
Bartish, G.I. et al. RAPD diversity in sea buckthorn

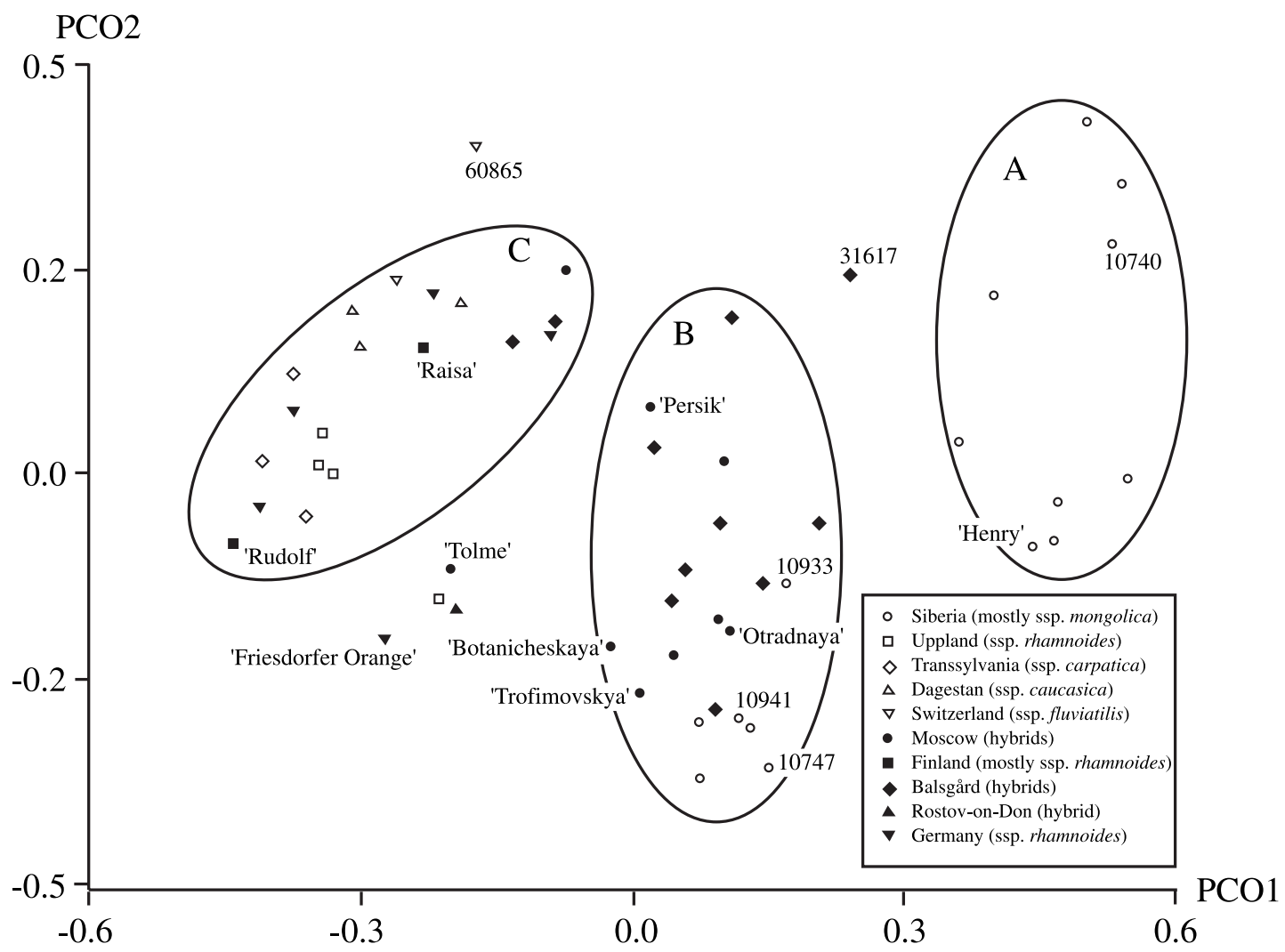

Fig. 2. Two-dimensional representation of the results of a principal co-ordinate analysis based on pairwise coefficients of similarity among 55 accessions of Hippophae rhamnoides. Percentages of variability explained by the two components: PCO1 $18.1 \%$, PCO2 $9.2 \%$.

accessions of the same subspecies, which indicates that some of those cultivars may have been derived through hybridization between different taxa. The Finnish cultivar 'Raisa' is actually a hybrid between ssp. rhamnoides and ssp. caucasica. The German cultivar 'Friesdorfer Orange' may also be of hybrid origin according to its placement far from the wild accessions. This is further supported by the UPGMA analysis where it was placed in group II, which consists mainly of hybrids.

Random mating of selected superior phenotypes, followed by mass selection in progenies, is a commonly practiced breeding strategy in fruit tree crops (Alston and Spiegel-Roy 1985). However, regardless of whether inbreeding should be avoided or promoted, information about the genetic relatedness of the breeding material is useful when trying to locate material with traits of interest and when designing a breeding programme. In the present study, RAPDs proved to be relatively efficient in grouping sea buckthorn genotypes according to their taxonomic classification and to their geographic origin. RAPDs have previously been used for successful geographic classification of cultivars of unknown origin, e.g. pistachio (Pistacia vera) (Hormaza et al. 1994).

It is not always straightforward to estimate genetic relatedness among accessions when based exclusively on pedigree information, especially not when only the maternal parent is 
Vol. 9 (2000): 279-289.

known as was the case for all halfsibs in our study. However, Garcia et al. (1998) reported a high correlation between RAPD-based similarity estimates and pedigree information in melon breeding lines. Moreover, in that material, RAPD markers appeared to be more suitable than agronomic traits in predicting genetic distance among different breeding lines. A good concordance between RAPD data and pedigree information was found in a set of strawberry cultivars (Hancock et al. 1994). Also in strawberries, a lack of agreement between RAPD-based similarity estimates and known pedigree data was, however, reported in another study (Graham et al. 1996), as well as a relatively weak agreement in a third study (Degani et al. 1998). In these latter studies, incorrect naming of parental clones and a low number of applied RAPD markers were suggested as the causes. Although no association was found between DNA markers and pedigree relationships in plantain and banana, different ploidy levels were represented and that may have seriously biased the expected contribution of parental genomes to the analyzed offspring (Tenkouano et al. 1999).

To set up a core collection, Brown (1989) suggests a stratified sampling approach: the whole collection is first divided into non-overlapping groups from which samples are taken by random. The hierarchy of grouping starts with taxonomy. The correct classification of the cultivated material of sea buckthorn is, in many cases, unknown. In addition, hybridization between subspecies is a common practise in many breeding programmes. Classification using morphological characters is not always reliable in these cases since neither leaves nor flowers offer many diagnostic features.

In the present study, the investigated plant collection was divided into three distinct groups by use of RAPD markers; 1) ssp. mongolica, 2) the European subspecies and 3) hybrids between ssp. mongolica and the European subspecies. To obtain a representation of wild material from different taxa, further collection in native stands can be recommended, since the exact origin will then be known. For the more heterogeneous cultivated material, however, RAPDs may serve as a useful classification tool. Agronomical as well as morphological traits should also be scored in addition to molecular markers since the core collection must provide a good representation of all traits found in the whole germplasm collection. However, in some cases a trait may be of polyphyletic origin (Gepts 1995). This may actually be quite common in cultivated plant material, since the aims of different breeding programmes are often similar, even if material from different origins has been used. In such cases, molecular markers can be used to ensure the conservation of different evolutionary lineages.

Acknowledgements. This study was funded by a grant from the Swedish Research Council for Forestry and Agriculture to HN.

\section{References}

Alston, F.H. \& Spiegel-Roy, P. 1985. Fruit tree breeding: strategies, achievements and constraints. In: Cannel, M.G.R. \& Jackson, J.E. (eds.). Attributes of trees as crop plants. Institute of Terrestrial Ecology, Huntingdon, UK. p. 49-67.

Bartish, I.V., Jeppsson, N., Bartish, G.I., Lu, R. \& Nybom, H. 2000. Inter- and intraspecific genetic variation in Hippophae (Elaeagnaceae) investigated by RAPD markers. Plant Systematics and Evolution 225 (in press).

- , Jeppsson, N. \& Nybom, H. 1999a. Population genet- ic structure in the dioecious pioneer plant species Hippophae rhamnoides investigated by random amplified polymorphic DNA (RAPD) markers. Molecular Ecology 8: 791-802.

- , Rumpunen, K. \& Nybom, H. 1999b. Genetic diversity in Chaenomeles (Rosaceae) revealed by RAPD analysis. Plant Systematics and Evolution 214: 131145.

Brown, A.H.D. 1989. Core collections: a practical approach to genetic resources management. Genome 31: 818-824. 


\section{AGRICULTURAL AND FOOD SCIENCE IN FINLAND}

Bartish, G.I. et al. RAPD diversity in sea buckthorn

Burmistrov, L.A. 1995. Genetic resources and breeding potential of sea buckthorn (Hippophae rhamnoides) in Russia. WANATCA Yearbook 19: 9-13.

Cardoso, M.A., Provan, J., Powell, W., Ferreiras, P.C.G. \& De Oliveira, D.E. 1998. High genetic differentiation among remnant populations of the endangered Caesalpinia echinata Lam. (Leguminosae-Caesalpinoideae). Molecular Ecology 7: 601-608.

Chalmers, K.J., Waugh, R., Sprent, J.I., Simons, A.J. \& Powell, W. 1992. Detection of genetic variation between and within populations of Gliricidia sepium and G. maculata using RAPD markers. Heredity 69: 465472.

Degani, C., Rowland, L.J., Levi, A., Hortynski, J.A. \& Galletta, G.J. 1998. DNA fingerprinting of strawberry (Fragaria $\mathrm{x}$ ananassa) cultivars using randomly amplified polymorphic DNA (RAPD) markers. Euphytica 102: 247-253.

Excoffier, L., Smouse, P.E. \& Quattro, J.M. 1992. Analysis of molecular variance inferred from metric distances among DNA haplotypes: application to human mitochondrial DNA restriction data. Genetics 131: 479-491.

Garcia, E., Jamilena, M., Alvarez, J.I., Arnedo, T., Oliver, J.L. \& Lozano, R. 1998. Genetic relationships among melon breeding lines revealed by RAPD markers and agronomic traits. Theoretical and Applied Genetics 96: 878-885.

Gepts, P. 1995. Genetic markers and core collections. In: Hodgkin, T. et al. (eds.). Core collections of plant genetic resources. John Wiley \& Sons, Chichester, UK. p. 127-146.

Gillies, A.C.M., Cornelius, J.P., Newton, A.C., Navarro, C., Hernández, M. \& Wilson, J. 1997. Genetic variation in Costa Rican populations of the tropical timber species Cedrela odorata L., assessed using RAPDs. Molecular Ecology 6: 1133-1145.

Graham, J., McNicol, R.J. \& McNicol, J.W. 1996. A comparison of methods for estimation of genetic diversity in strawberry cultivars. Theoretical and Applied Genetics 93: 402-406.

Hancock, J.F., Callow, P.A. \& Shaw, D.V. 1994. Randomly amplified polymorphic DNAs in the cultivated strawberry (Fragaria x ananassa). Journal of the American Society of Horticultural Science 118: 862-864.

Hokanson, S.C., Szewc-McFadden, A.K., Lamboy, W.F. \& McFerson, J.R. 1998. Microsatellite (SSR) markers reveal genetic identities, genetic diversity and relationships in a Malus $\mathrm{x}$ domestica Borkh. core subset collection. Theoretical and Applied Genetics 97: 671-683.

Hormaza, J.I., Dollo, L. \& Polito, V.S. 1994. Determination of relatedness and geographical movements of Pistacia vera (Pistachio; Anacardiaceae) germplasm by RAPD analysis. Economic Botany 48: 349-358. Huff, D.R., Peakall, R. \& Smouse, P.E. 1993. RAPD variation within and among natural population of outcrossing buffalograss (Buchloe dactyloides (Nutt.) Engelm.). Theoretical and Applied Genetics 86: 927934.

Kalinina, I.P. \& Panteleyeva, Y.I. 1987. Breeding of sea bucktorn in the Altaj. In: Hryukov, A.B. (ed.). Advances in agricultural science. Moscow. p. 76-87.

Mikheyev, A.M. \& Demenko, V.I. 1990. Oblepiha. Rosagropromizdat. Moscow.

Persson, H.A. \& Nybom, H. 1999. Genetic sex determination and RAPD marker segregation in the dioecious species sea buckthorn (Hippophae rhamnoides L.). Hereditas 129: 45-51.

Rohlf, F.J. 1997. NTSYS-pc. Numerical taxonomy and multivariate analysis system, version 1.80. Exeter Software, Setauket, NY.

Rossetto, M., Weaver, P.K. \& Dixon, K.W. 1995. Use of the RAPD analysis in devising conservation strategies for the rare and endangered Grevillea scapigera (Proteaceae). Molecular Ecology 4: 321-329.

Rousi, A. 1971. The genus Hippophae L. A taxonomic study. Annales Botanici Fennici 8: 177-227.

Russell, J.R., Hosein, F., Johnson, E., Waugh, R. \& Powell, W. 1993. Genetic differentiation of cocoa (Theobroma cacao L.) populations revealed by RAPD analysis. Molecular Ecology 2: 89-97.

Sydes, M.A. \& Peakall, R. 1998. Extensive clonality in the endangered shrub Haloragodendron lucasii (Haloragaceae) revealed by allozymes and RAPDs. Molecular Ecology 7: 87-93.

Tenkouano, A., Crouch, J.H., Crouch, H.K., Vuylsteke, D. \& Ortiz, R. 1999. Comparison of DNA marker and pedigree-based methods of genetic analysis of plantain and banana (Musa spp.) clones. I. Estimation of genetic relationships. Theoretical and Applied Genetics 98: 62-68.

Tivang, J., Skroch, P. \& Nienhuis, J. 1996. Randomly amplified polymorphic DNA (RAPD) variation among and within artichoke (Cynara scolymus L.) cultivars and breeding populations. Journal of the American Society of Horticultural Science 121: 783-788.

Trajkovski, V. \& Jeppsson, N. 1999. Domestication of sea buckthorn. Botanica Lithuanica, suppl. 2: 37-46.

Virk, P.S., Zhu, J., Newbury, H.J., Bryan, G.J., Jackson, M.T. \& Ford-Lloyd, B.V. 2000. Effectiveness of different classes of molecular marker for classifying and revealing variation in rice (Oryza sativa) germplasm. Euphytica 112: 275-284.

Weising, K., Nybom, H., Wolff, K. \& Meyer, W. 1994. DNA fingerprinting in plants and fungi. CRC Press, Boca Raton, FL. 
Vol. 9 (2000): 279-289.

\section{SELOSTUS}

\section{Tyrnin geneettisen monimuotoisuuden arviointi RAPD analyysillä}

Galyna I. Bartish, Niklas Jeppsson, Igor V. Bartish ja Hilde Nybom

Swedish University of Agricultural Sciences, Ruotsi

RAPD (Random amplified polymorphic DNA)-markkerien avulla kuvailtiin osaa tyrnin geenipankista, joka oli koottu jalostustarkoituksiin. Molekyylimarkkereita monistettiin 55 näytteestä, jotka edustivat viittä tyrnin (Hippophae rhamnoides L.) alalajia ja eri alalajien välisiä hybridejä. Kuudenkymmenenkolmen markkerin avulla laskettiin Dicen samankaltaisuuskerroinmatriisi (Dice's similarity coefficient matrix) yksittäisten RAPD profiilien parittaisista vertailuista. Matriisiin perustuvien analyysien (UPGMA- and principal co-ordinate analyses) avulla kasvit jakautuivat ryhmiin, jotka vastaavat niiden taksonomista luokkaa ja maantieteellistä alkuperää. AMOVA-ana- lyysi (analysis of molecular variance) todettiin käyttökelpoiseksi menetelmäksi arvioitaessa näytteiden taksonomisten ja maantieteellisten ryhmien välisiä ja sisäisiä geneettisen muuntelun osatekijöitä. Vaikka molemmista aineiston ryhmittelyvaihtoehdoista (taksonominen ja maantieteellinen alkuperä) paljastui ryhmien välistä muuntelua, pääosa molekyylivarianssista (arviolta $75 \%$ ) luettiin yhä ryhmien sisäisen muuntelun aiheuttamaksi. Yhteenvetona toteamme, että RAPD analyysi on käyttökelpoinen menetelmä tyrninäytteiden taksonomisen ja maantieteellisen alkuperän selvittämiseen. 